\title{
Critical analysis of anti-TNF use in the era of new biological agents in inflammatory bowel disease
}

\author{
Camila Cunha Gonzaga LIMA'1 Natália Sousa Freitas QUEIROZ', Carlos Walter SOBRADO², \\ Gustavo Luís Rodela SILVA ${ }^{3}$ and Sérgio Carlos NAHAS ${ }^{2}$
}

Received: 15 May 2020 Accepted: 29 June 2020

\begin{abstract}
Background - Inflammatory bowel diseases (IBD), both Crohn's disease and ulcerative colitis, are chronic immune-mediated diseases that present a relapsing and remitting course and requires long-term treatment. Anti-tumor necrosis factor (anti-TNF) therapy has changed the management of the disease by reducing the need for hospitalizations, surgeries and improving patient's quality of life. Objective - The aim of this review is to discuss the role of anti-TNF agents in IBD, highlighting the situations where its use as first-line therapy would be appropriate. Methods - Narrative review summarizing the best available evidence on the topic based on searches in databases such as MedLine and PubMed up to April 2020 using the following keywords: "inflammatory bowel disease", "anti-TNF agents" and "biologic therapy". Conclusion - Biological therapy remains the cornerstone in the treatment of IBD. In the absence of head-to-head comparisons, the choice of the biological agent may be challenging and should take into account several variables. Anti-TNF agents should be considered as first line therapy in specific scenarios such as acute severe ulcerative colitis, fistulizing Crohn's disease and extra-intestinal manifestations of IBD, given the strong body of evidence supporting its efficacy and safety in these situations.
\end{abstract}

HEADINGS - Inflammatory bowel diseases. Tumor necrosis factor-alpha, antagonists \& inhibitors. Biologic therapy. Crohn disease, drug therapy. Ulcerative colitis, drug therapy.

\section{INTRODUCTION}

In the last two decades anti-tumor necrosis factor (anti-TNF) therapy has been widely used for the treatment of inflammatory bowel disease (IBD) changing the management of the disease. Data have been accumulated demonstrating the efficacy of these agents in inducing mucosal healing, reducing the need for hospitalizations, surgeries and improving patient's quality of life ${ }^{(1,2)}$. Unfortunately, roughly one third of patients are primary non responders and, among responders, dose intensification is needed in $23 \%-46 \%$ of patients and drug discontinuation occurs in 5\%-13\% of patients yearly ${ }^{(3,4)}$. With the advances in the understanding of the pathological mechanisms involved in IBD, new biologic agents with different mechanisms of action or small molecules targeting intracellular pathways were recently approved. Within this scenario, the aim of this review is to discuss the role of anti-TNF agents (infliximab, adalimumab, certolizumab and golimumab) in IBD as a therapeutic option in the era of biologics with other mechanisms of action highlighting the situations where its use as first line therapy would be appropriate.

\section{CROHN'S DISEASE}

\section{Anti-TNF inducing remission}

The great landmark in biological therapy occurred in 1997, when Targan et al. ${ }^{(5)}$ published the first study (multicenter, double-blind) involving 108 patients with moderate to severe Crohn's disease (CD) refractory to steroids and aminosalicylates. Patients received infliximab (IFX) single doses of $5 \mathrm{mg} / \mathrm{kg}, 10$ $\mathrm{mg} / \mathrm{kg}, 20 \mathrm{mg} / \mathrm{kg}$ or placebo. Comparing IFX with placebo up to four weeks, the clinical response rate, as well as remission rate, was superior in the placebo group (65\% IFX vs $17 \%$ placebo; $33 \%$ IFX vs $4 \%$ placebo, respectively). According to CLASSIC I study(6) (double-blind, placebo-controlled RCT) the efficacy of adalimumab (ADA) was demonstrated in a group of 299 patients with moderate to severe CD naïve to anti-TNF. At week 4, higher rates of clinical remission were observed in ADA group (dose of $160 \mathrm{mg}$ at week $0 ; 80 \mathrm{mg}$ at week 2) than in the placebo group (36 $\%$ vs $12 \%$, respectively). Additionally, improvement of symptoms was observed in $59 \%$ of patients on ADA treatment vs $37 \%$ in placebo group.

\section{Anti-TNF inducing maintenance of remission}

The efficacy of IFX in maintaining clinical response in CD was demonstrated in ACCENT $\mathbf{I}^{(7)}$ (multicenter, double-blind, randomized controlled trial) that involved 335 patients with luminal $\mathrm{CD}$ which responded to a single infusion of IFX within 2 weeks. At week 30 , clinical remission was achieved in $39 \%$ of patients (IFX $5 \mathrm{mg} / \mathrm{kg}$ every 8 weeks) as compared to $21 \%$ in the placebo group. After week $54,40 \%$ of the biological group achieved clinical remis-

Declared conflict of interest of all authors: Lima CCG: Nahas SC and Silva GLR declares no potential conflicts of interest; Sobrado CW has served as a consultant to Takeda, Farmoquímica; Queiroz NSF reports receiving consulting fees from Janssen; lecture fees from Janssen, Takeda, UCB, and Abbvie; and travel grant support from Takeda, Janssen, and Abbvie. Disclosure of funding: no funding received.

${ }^{1}$ Universidade de São Paulo, Faculdade de Medicina, Departamento de Gastroenterologia, São Paulo, SP, Brasil. ${ }^{2}$ Universidade de São Paulo, Faculdade de Medicina, Departamento de Gastroenterologia e Divisão de Coloproctologia, São Paulo, SP, Brasil. ${ }^{3}$ Universidade de São Paulo, Faculdade de Medicina, Departamento de Gastroenterologia e Divisão de Endoscopia Digestiva, São Paulo, SP, Brasil.

Corresponding author: Camila Cunha Gonzaga Lima. E-mail: cacunhag@gmail.com 
sion with corticosteroid withdrawal vs $15.0 \%$ in the placebo group. This data shows the effectiveness of IFX therapy in maintaining response for a longer period of time.

The long-term effectiveness of IFX treatment was assessed in a real-life cohort ${ }^{(8)}$ including 614 patients followed for a median of 55 months. The study demonstrated that approximately $11 \%$ of patients were primary non-responders and that the majority of responders had sustained clinical benefit with biological therapy $(63.4 \%)$. The treatment was discontinued in $31.7 \%$ of patients due to complete remission, in $21.6 \%$ due to loss of response and in $12.8 \%$ due to adverse events. Thus, this study reinforced preliminary pivotal data in the real world setting.

Despite no head-to-head trial is available, indirect comparisons suggest that IFX or ADA may be preferred first-line agents for induction of remission in patients with moderate to severe CD. A recent metanalysis by Singh et al..$^{(9)}$ showed that all agents (IFX, ADA, Vedolizumab and Ustekinumab), except Certolizumab pegol, were superior to placebo for induction of clinical remission and effect size was strongest for IFX and ADA. In biologic-naïve patients and patients with response to induction therapy, IFX and ADA were ranked highest for induction of clinical remission and maintenance of remission.

\section{Fistulizing Crohn's disease}

The importance of anti-TNF therapies in fistulazing disease (abdominal or perianal) comes from one positive study (multicenter, double-blind-placebo-controlled trial) headed by Present et al. ${ }^{(10)}$, which enrolled 94 patients who had draining abdominal or perianal fistulas for at least three months. Patients received IFX $(5 \mathrm{mg} / \mathrm{kg}$ or $10 \mathrm{mg} / \mathrm{kg}$ at weeks 0,2 and 6) and the primary outcome was a $50 \%$ reduction in the drainage of fistula. At 18 weeks followup, fistula healing occurred in $68 \%(5 \mathrm{mg} / \mathrm{kg}), 56 \%(10 \mathrm{mg} / \mathrm{kg})$ and $26 \%$ (placebo) of patients. The ACCENT II ${ }^{(11)}$ (multicenter, double-blind, randomized, placebo-controlled trial) enrolled 306 patients with $\mathrm{CD}$ and one or more fistulas with active drainage. Patients responding to induction therapy (IFX $5 \mathrm{mg} / \mathrm{kg}$ at weeks $0,2,6$ ) had an increased likelihood of a sustained response over a $54-w e e k$ period compared with placebo (36\% vs $19 \%$, respectively), reinforcing the role of IFX maintenance therapy in fistulazing CD.

Regarding ADA therapy, there are no trials investigating fistula closure as primary endpoint. However, the subgroup analysis of the maintenance trial with ADA (CHARM) ${ }^{(12)}$ observed that complete fistula closure was achieved in a greater percentage of ADA-treated patients vs those receiving placebo (30\% vs $13 \%$, at week $26 ; 33 \%$ vs $13 \%$, at week 56 ; respectively).

\section{Prevention of postoperative clinical recurrence}

Despite developments in medical therapy, surgical intervention may be required in up to $75 \%$ of CD patients 10 years from diagno$\operatorname{sis}^{(13,14)}$. Since surgery is not curative, clinical recurrence is reported in $50 \%$ of patients and endoscopic recurrence in $80 \%$ of patients in the first year after surgery. ${ }^{(15)}$. Anti-TNF agents, specifically IFX and adalimumab ADA, seem to be the most effective therapy for preventing postoperative recurrence.

Regueiro et al. ${ }^{(16)}$, in 2009 , demonstrated in the first placebocontrolled randomized trial that endoscopic recurrence was significantly lower in the IFX group compared with controls at the first year after surgery $(9.1 \%$ vs $84.6 \%)$. Similarly, the PREVENT trial $^{(17)}$ (multicenter, placebo-controlled RCT) enrolled 297 patients undergoing ileocolonic resection within 45 days before randomiza- tion and observed that before or at week 76 a significantly lower proportion of patients in the IFX group ( $5 \mathrm{mg} / \mathrm{kg}$, every 8 weeks) had endoscopic recurrence compared with the placebo group (30.6\% vs 60.0\%, respectively).

Different strategies for prevention of postoperative recurrence were assessed in the POCER study ${ }^{(18)}$ which enrolled 101 patients at high risk of disease recurrence, after a three months trial of antibiotics. High-risk patients (smoker, penetrating disease, $\geq$ second operation) received thiopurine (or every other week ADA if thiopurine intolerant). At 6 months, endoscopic recurrence was demonstrated in $39 \%$ of patients in the thiopurine group and in $13 \%$ of patients in the ADA group. Similarly, Savarino et al. compared the efficacy of ADA, mesalamine and azathioprine in prevention of recurrence ${ }^{(19)}$. After 2 years, endoscopic recurrence was significantly lower in the ADA group (6.3\%) as compared with the AZA patients $(64.7 \%)$ and mesalamine group $(83.3 \%)$. Clinical recurrence was also lower in the ADA group $(12.5 \%)$ compared with AZA $(64.7 \%)$ and mesalamine patients $(50 \%)$. This data highlights that anti-TNF treatment exhibits higher efficacy in prevention of postoperative recurrence as compared with conventional therapy (FIGURE 1).

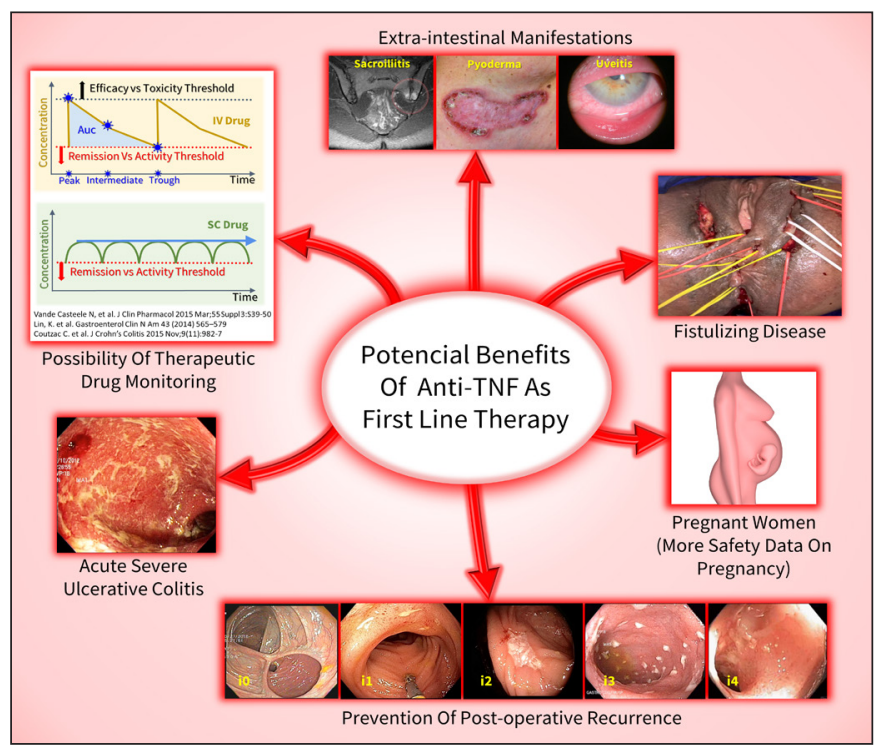

FIGURE 1. The role of anti-TNF agents in the setting of inflammatory bowel disease.

The trials that assessed the efficacy of anti-TNF agents in CD patients are summarized in TABLE 1 .

\section{ULCERATIVE COLITIS}

\section{Anti-TNF inducing remission}

Definitive evidence for the efficacy of IFX in the treatment of ulcerative colitis (UC) was offered by the two large placebo-controlled clinical trials ACT-1 and ACT-2. In these studies, Rutgeerts et al. ${ }^{(20)}$ assessed the IFX effectiveness in induction and maintenance of clinical response obtained at 8 weeks with IFX (weeks $0,2,6$ followed by infusions every 8 weeks) in patients with Mayo score 6-12. At week 8 , clinical response was superior in both groups (5 $\mathrm{mg} / \mathrm{kg}$ or $10 \mathrm{mg} / \mathrm{kg}$ ) when compared to placebo. The efficacy of ADA in induction of clinical remission in UC patients was also assessed in ULTRA I Trial ${ }^{(21)}$ that included patients with moderate 
TABLE 1. Characteristics of included trials comparing different biologic agents for patients with moderate-severe Crohn's disease.

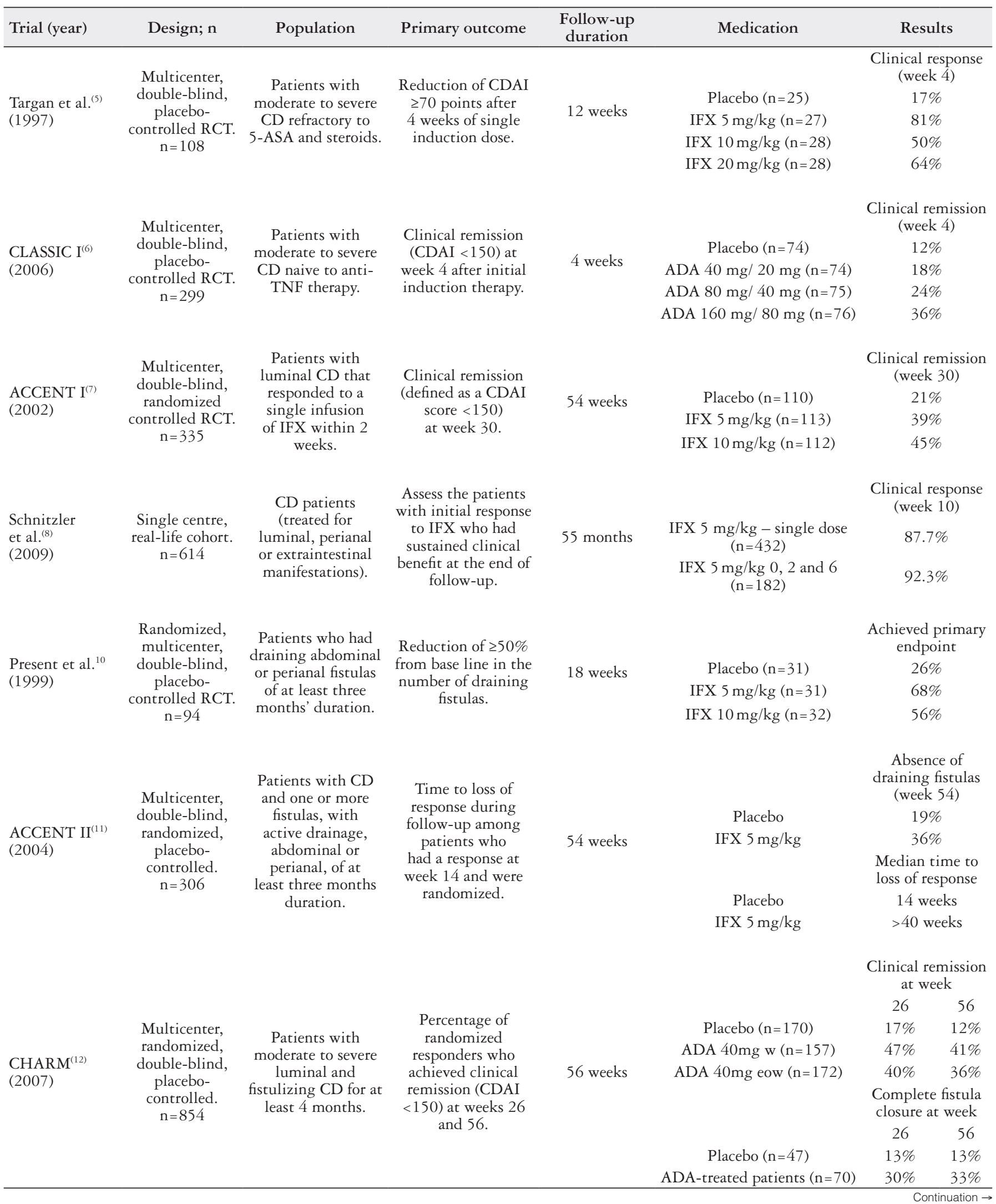




\begin{tabular}{|c|c|c|c|c|c|c|}
\hline Trial (year) & Design; n & Population & Primary outcome & $\begin{array}{c}\text { Follow-up } \\
\text { duration }\end{array}$ & Medication & Results \\
\hline $\begin{array}{l}\text { Regueiro } \\
\text { et al. }{ }^{13} \\
(2009)\end{array}$ & $\begin{array}{c}\text { Randomized, } \\
\text { double-blind, } \\
\text { placebo- } \\
\text { controlled RCT. } \\
\text { n=24 }\end{array}$ & $\begin{array}{l}\text { Patients with CD } \\
\text { who had undergone } \\
\text { ileocolonic } \\
\text { resection and } \\
\text { were allocated to } \\
\text { receive intravenous } \\
\text { IFX or placebo } \\
\text { administered within } \\
4 \text { weeks of surgery } \\
\text { and continued for } \\
1 \text { year. }\end{array}$ & $\begin{array}{l}\text { Proportion of } \\
\text { patients with } \\
\text { endoscopic } \\
\text { recurrence at } 1 \text { year } \\
\text { after surgery. }\end{array}$ & 1 year & $\begin{array}{l}\text { Placebo }(\mathrm{n}=13) \\
\text { IFX } 5 \mathrm{mg} / \mathrm{kg}(\mathrm{n}=11)\end{array}$ & $\begin{array}{l}\text { Endoscopic } \\
\text { recurrence } \\
\text { (1 year) } \\
84.6 \%\end{array}$ \\
\hline $\begin{array}{l}\text { PREVENT }^{17} \\
(2016)\end{array}$ & $\begin{array}{l}\text { Multicenter, } \\
\text { randomized, } \\
\text { double-blind, } \\
\text { placebo- } \\
\text { controlled RCT. } \\
\text { n=297 }\end{array}$ & $\begin{array}{l}\text { Patients with } \\
\text { CD which had } \\
\text { undergone } \\
\text { ileocolonic } \\
\text { resection within } \\
45 \text { days before } \\
\text { randomization. }\end{array}$ & $\begin{array}{l}\text { Clinical recurrence } \\
\text { prior to or at week } \\
76 \text { and evidence } \\
\text { of endoscopic } \\
\text { recurrence. }\end{array}$ & 76 weeks & $\begin{array}{c}\text { Placebo }(n=150) \\
\text { IFX } 5 \mathrm{mg} / \mathrm{kg}(\mathrm{n}=147)\end{array}$ & $\begin{array}{c}\text { Endoscopic } \\
\text { recurrence }(\leq 76 \\
\text { weeks }) \\
60.0 \% \\
30.6 \%\end{array}$ \\
\hline $\begin{array}{l}\text { POCER }^{18} \\
(2015)\end{array}$ & $\begin{array}{l}\text { Part of } \\
\text { multicenter, } \\
\text { randomized, } \\
\text { double-blind, } \\
\text { placebo- } \\
\text { controlled RCT. } \\
\mathrm{n}=101\end{array}$ & $\begin{array}{l}\text { Patients with } \\
\text { CD undergoing } \\
\text { intestinal resection } \\
\text { of all macroscopic } \\
\text { disease, with an } \\
\text { endoscopically } \\
\text { accessible } \\
\text { anastomosis. }\end{array}$ & $\begin{array}{l}\text { Presence and severity } \\
\text { of endoscopic } \\
\text { recurrence } 6 \text { months } \\
\text { after surgery. }\end{array}$ & 6 months & $\begin{array}{l}\text { Colonoscopy at } 6 \text { month } \\
\text { post-operatively } \\
\text { Thiopurine }(n=62) \\
\text { ADA } 160 / 80 \text { (followed by } \\
40 \text { mg eow) }(n=24)\end{array}$ & $\begin{array}{c}\text { Endoscopic } \\
\text { recurrence } \\
39 \%\end{array}$ \\
\hline $\begin{array}{l}\text { Savarino et al. }{ }^{19} \\
(2013)\end{array}$ & $\begin{array}{l}\text { Randomized, } \\
\text { prospective, } \\
\text { three-armed, } \\
\text { unblended. } \\
\text { n=51 }\end{array}$ & $\begin{array}{l}\text { Patients with } \\
\text { ileal or ileocolonic } \\
\text { CD undergoing } \\
\text { resection to receive } \\
\text { after } 2 \text { weeks from } \\
\text { surgery ADA, AZA } \\
\text { or Mesalamine. }\end{array}$ & $\begin{array}{c}\text { Proportion of } \\
\text { patients with } \\
\text { endoscopic and } \\
\text { clinical recurrence at } \\
2 \text { years after surgery. }\end{array}$ & 2 years & $\begin{array}{l}\text { ADA } 160 / 80 \mathrm{mg} \text { (followed } \\
\text { by } 40 \mathrm{mg} \text { eow) }(\mathrm{n}=16) \\
\text { AZA } 2 \mathrm{mg} / \mathrm{kg} / \text { day }(\mathrm{n}=17) \\
\text { Mesalamine } 3 \mathrm{~g} / \text { day }(\mathrm{n}=18)\end{array}$ & $\begin{array}{c}\text { Endoscopic } \\
\text { recurrence } \\
6.3 \% \\
64.7 \% \\
83.3 \%\end{array}$ \\
\hline
\end{tabular}

ADA: adalimumab; IFX: infliximab; RCT: randomized controlled trials; CDAI: Crohn's Disease Activity Index; eow: every other week; w: weekly.

to severe UC which were treated with ADA $160 / 80 \mathrm{mg}$ or $80 / 40$ $\mathrm{mg}$ or placebo at weeks 0 and 2 . At week 8 , clinical remission was achieved in $18.5 \%$ of patients on ADA $160 / 80 \mathrm{mg}, 10.0 \%$ on ADA $80 / 40 \mathrm{mg}$, and $9.2 \%$ in the placebo group. It has been speculated that higher loading doses of ADA could improve clinical outcomes in CD and, specifically, in UC. However, preliminary data from SERENE-UC Trial ${ }^{(22)}$ has not proven this hypothesis through the evaluation of clinical and endoscopic response after 8 weeks induction period with loading doses of ADA (160 mg at weeks $0,1,2$, and 3 , followed by $40 \mathrm{mg}$ at weeks 4 and 6) compared to standard dose (160 mg at week 0 and $80 \mathrm{mg}$ at week 2, followed by $40 \mathrm{mg}$ at weeks 4 and 6). Data regarding long term outcomes are still awaited.

\section{Anti-TNF inducing maintenance of remission}

The effect of maintenance therapy with IFX over placebo was also demonstrated in ACT I and ACT II trials ${ }^{(20)}$. At week 30 , clinical response rates of $48.8 \%$ ( $5 \mathrm{mg} / \mathrm{kg}$ group), $45.9 \%$ (10 $\mathrm{mg} / \mathrm{kg}$ group) and $23.1 \%$ (placebo group) were observed in ACT I; and $41.3 \%(5 \mathrm{mg} / \mathrm{kg}), 53.3 \%(10 \mathrm{mg} / \mathrm{kg})$ and $15.4 \%$ (placebo) in ACT II. (10 mg/kg group) and $23.1 \%$ (placebo group) in ACT $\mathrm{I}$; and $41.3 \%$ (5 mg/kg), 53.3\% (10 mg/kg) compared $15.4 \%$ (placebo) in ACT II.
The ULTRA 2 study $^{(23)}$ (multicenter, randomized, double-blind, placebo-controlled, phase III) was conducted to further investigate the long-term efficacy of ADA in patients with moderate to severe UC that had previously been exposed or not to anti-TNF therapy. At week 52, clinical remission was documented in $17.3 \%$ of patients treated with ADA (40 mg every other week) vs $8.5 \%$ of patients treated with placebo. Accordingly, real-life data ${ }^{(24)}$ demonstrate higher rates of induction and maintenance of remission in with ADA treatment. A recent Italian study ${ }^{(24)}$ showed that $54,9 \%$ of patients achieved clinical remission and the drug was maintained in $56,6 \%$ of the patients during a median follow-up of 18 months.

According to PURSUIT- M study ${ }^{(25)}$, which analyzed maintenance therapy with Golimumab (GOL) in responders to induction therapy, clinical response, at week 54 , was seen in $47.0 \%$ of patients on GOL $50 \mathrm{mg}$ every 4 weeks and $49.7 \%$ of patients on GOL $100 \mathrm{mg}$ administered in the same interval. Comparing to placebo, $31.2 \%$ had clinical response, reinforcing the superiority of this drug over placebo in the maintenance of remission in UC.

Recently, through a systematic review and network metaanalysis, Singh et al. ${ }^{(26)}$, assessed the comparative efficacy and safety of different therapies as first-line (biologic-naïve) and second-line (prior exposure to anti-tumour necrosis factor) therapy through the analysis of randomized controlled trials 
(RCTs) in adults with moderate-severe UC treated with anti-TNF agents, anti-integrin agents and janus kinase (JAK) inhibitors. In biologic-naïve patients, it was observed that all agents (IFX, ADA, GOL, vedolizumabe and tofacitinibe) were superior to placebo for induction of mucosal healing and effect size was strongest for IFX and vedolizumab. As compared to IFX and ADA as first-line therapy, data have shown superiority of IFX over ADA for inducing clinical response and decreasing the risk of hospitalisation.

\section{Acute severe ulcerative colitis}

Sands et al. ${ }^{(27)}$ conducted the first trial in the setting of acute severe UC (ASUC), which enrolled which enrolled 11 steroidrefractory patients. After a 2 week follow-up, patients that received a single infusion of $\operatorname{IFX}(5,10$ or $20 \mathrm{mg} / \mathrm{kg})$ achieved $50 \%$ of response to treatment compared to no response in the placebo group. Subsequently, in 2005, Jarnerot et al. ${ }^{(28)}$ evaluated 45 patients with ASUC refractory to high doses of intravenous corticosteroids. Greater efficacy was observed in patients that undergone a single dose of IFX $(5 \mathrm{mg} / \mathrm{kg})$ when compared to placebo at 3 months of follow-up. Regarding colectomy rates, $29 \%$ of patients required surgery in the IFX group vs $67 \%$ in the placebo group. In a long-term follow-up (3 years) ${ }^{(29)}$, biological therapy showed sustained benefit with colectomy rates of $50 \%$ in the IFX group compared to $76 \%$ in the placebo group.

Many studies have highlighted the importance of accelerated IFX induction regimen in ASUC. In this context, Gibson et al. ${ }^{(30)}$ demonstrated that, at 3 months of follow-up, $6.7 \%$ of patients in the accelerated regimen group (three doses of IFX over 2 weeks) demanded colectomy vs $40 \%$ of patients that received IFX induction in a standard dose of 6 weeks, showing that IFX intensified dosing induction regimen could improve the efficacy of this drug in decreasing the need for early colectomy.

However, a recent metanalysis ${ }^{(31)}$ have not confirmed this initial data and found no association between accelerated IFX induction therapy and lower rates of colectomy in patients with ASUC compared to standard induction therapy.

The summary of studies evaluating efficacy of anti-TNF agents in UC patients are listed in TABLE 2.

TABLE 2. Characteristics of included controlled trials comparing different biologic agents for patients with for moderate-severe ulcerative colitis.

\begin{tabular}{|c|c|c|c|c|c|c|c|}
\hline Trial (year) & Design; $\mathrm{n}$ & Population & Primary outcome & $\begin{array}{l}\text { Follow-up } \\
\text { duration }\end{array}$ & Medication & \multicolumn{2}{|c|}{ Results } \\
\hline \multirow{3}{*}{$\begin{array}{l}\text { ACT } 1^{(20)} \\
(2005)\end{array}$} & \multirow{3}{*}{$\begin{array}{l}\text { Multicenter, } \\
\text { randomized, } \\
\text { double-blind, } \\
\text { placebo- } \\
\text { controlled RCT. } \\
\text { n=364 }\end{array}$} & \multirow{3}{*}{$\begin{array}{l}\text { Patients with } \\
\text { moderate-to- } \\
\text { severe active } \\
\text { ulcerative colitis } \\
\text { despite treatment } \\
\text { with concurrent } \\
\text { medications. }\end{array}$} & \multirow{3}{*}{$\begin{array}{l}\text { Clinical response } \\
\text { at week } 8 \text { and } \\
\text { secondarily, } \\
\text { clinical response } \\
\text { or remission and } \\
\text { mucosal healing at } \\
\text { weeks } 8,30 \text {, and } 54 .\end{array}$} & \multirow{3}{*}{54 weeks } & & \multicolumn{2}{|c|}{$\begin{array}{l}\text { Clinical response } \\
\text { at week }\end{array}$} \\
\hline & & & & & Placebo $(n=121)$ & $37.2 \%$ & $19.8 \%$ \\
\hline & & & & & IFX $5 \mathrm{mg} / \mathrm{kg}(\mathrm{n}=121)$ & $69.4 \%$ & $45.5 \%$ \\
\hline \multirow{3}{*}{$\begin{array}{l}\operatorname{ACT~} 2^{(20)} \\
(2005)\end{array}$} & \multirow{3}{*}{$\begin{array}{c}\text { Multicenter, } \\
\text { randomized, } \\
\text { double-blind, } \\
\text { placebo- } \\
\text { controlled RCT. } \\
\text { n=364 }\end{array}$} & \multirow{3}{*}{$\begin{array}{l}\text { Patients with } \\
\text { moderate-to- } \\
\text { severe active } \\
\text { ulcerative colitis } \\
\text { despite treatment } \\
\text { with concurrent } \\
\text { medications. }\end{array}$} & \multirow{3}{*}{$\begin{array}{l}\text { Clinical response } \\
\text { at week } 8 \text { and } \\
\text { secondarily, } \\
\text { clinical response } \\
\text { or remission and } \\
\text { mucosal healing at } \\
\text { weeks } 8 \text { and } 30 \text {. }\end{array}$} & & & \multicolumn{2}{|c|}{$\begin{array}{c}\text { Clinical response } \\
\text { at week }\end{array}$} \\
\hline & & & & & & 8 & 30 \\
\hline & & & & 30 weeks & Placebo $(n=123)$ & $29.3 \%$ & $26.0 \%$ \\
\hline \multirow{4}{*}{$\begin{array}{l}\text { ULTRA I }^{(21)} \\
(2011)\end{array}$} & \multirow{4}{*}{$\begin{array}{l}\text { Multicenter, } \\
\text { randomized, } \\
\text { double-blind, } \\
\text { placebo- } \\
\text { controlled RCT. } \\
\text { n=390 }\end{array}$} & \multirow{4}{*}{$\begin{array}{l}\text { Anti-TNF nave } \\
\text { patients with } \\
\text { moderate-to-severe } \\
\text { active ulcerative } \\
\text { colitis. }\end{array}$} & \multirow{4}{*}{$\begin{array}{l}\text { Clinical remission at } \\
\text { week } 8 \text { after initial } \\
\text { induction therapy. }\end{array}$} & \multirow{4}{*}{8 weeks } & & \multicolumn{2}{|c|}{$\begin{array}{l}\text { Clinical response } \\
\quad \text { (week 8) }\end{array}$} \\
\hline & & & & & Placebo $(n=130)$ & \multicolumn{2}{|c|}{$9.2 \%$} \\
\hline & & & & & $\begin{array}{c}\text { ADA } 80 / 40 \text { (followed by } 40 \\
\text { mg EOW) }(n=130)\end{array}$ & \multicolumn{2}{|c|}{$10.0 \%$} \\
\hline & & & & & $\begin{array}{l}\text { ADA 160/80 (followed by } \\
40 \text { mg EOW ) }(n=130)\end{array}$ & \multicolumn{2}{|c|}{$18.5 \%$} \\
\hline $\begin{array}{l}\text { SERENE- UC } \\
\text { (2019) }\end{array}$ & $\begin{array}{c}\text { Multicenter, } \\
\text { randomized, } \\
\text { double-blind. } \\
\mathrm{n}=852\end{array}$ & $\begin{array}{l}\text { Patients with } \\
\text { moderate-to-severe } \\
\text { active ulcerative } \\
\text { colitis. }\end{array}$ & $\begin{array}{l}\text { Clinical remission } \\
\text { at week } 8 .\end{array}$ & 8 weeks & & \multicolumn{2}{|c|}{$\begin{array}{l}\text { Clinical remission } \\
\quad \text { (week 8) }\end{array}$} \\
\hline
\end{tabular}






ADA: adalimumab; IFX: infliximab; GOL: golimumab; RCT: randomized controlled trials; EOW: every other week.

\section{SPECIFIC SITUATIONS}

\section{Pregnancy}

Many studies have evaluated the safety profile of anti-TNF drugs in the setting of pregnancy. With exception of Certolizumab (CZP), which has minimal placental transfer, others anti-TNF agents (IFX and ADA) are actively transported across the placenta since the13th week ${ }^{(32)}$.

Preliminary data from the PIANO registry ${ }^{(33)}$, an extensive database that evaluated pregnant women using biologics, concluded that there were no differences in the rate of congenital malformations, preterm births, or other adverse events in pregnant women exposed to anti-TNF compared to patients exposed to thiopurines and the control group. Conversely, data from the EVASION study ${ }^{(34)}$ have demonstrated an increased risk of maternal complication, mainly infections, in pregnant women exposed to anti-TNF. However, exposition to biologics during pregnancy was not associated with increased risk of infection in the offspring during the first year of life. Regarding the risk of complications, no differences were reported between women treated during the third trimester and those 
which stopped anti-TNF at, or before 24 weeks of amenorrhea (as recommended by guidelines $)^{(35)}$.

No data showed increased rate of spontaneous miscarriages, stillbirths, preterm deliveries or congenital malformations with the use of ADA during pregnancy. Even though anti-TNF therapy can be considered safe in the early stages of pregnancy, the guidelines recommend temporary discontinuation of treatment around gestational week 24-26 in patients presenting sustained remission ${ }^{(35)}$.

\section{Extraintestinal manifestations}

Extraintestinal manifestations (EIM) in IBD are most frequently reported in joints (peripheral and axial arthropathies), skin, hepatobiliary tract, and eyes. In this setting, the frequencies of involvement range from $6 \%$ to $47 \%{ }^{(36-38)}$. Anti-TNF drugs have significantly changed the management of EIM in IBD patients. A study headed by Caspersen and colleagues ${ }^{(39)}$ observed that patients with CD on IFX presented $80 \%$ of improvement or remission in skin or joint symptoms with biological therapy. Similarly, in an open-label study, Barreiro-de-Acosta et al. ${ }^{(40)}$ concluded that $66.7 \%$ of CD patients with at least one EIM that received ADA on standard dose achieved remission $(38.1 \%)$ or any response $(28.5 \%)$ of the EIM.

A recent systematic review ${ }^{(41)}$ has further corroborated the benefits of anti-TNF treatment in EIM through the analysis of 9 interventional studies and 13 non-interventional studies. Regarding patients with pyoderma gangrenosum under anti-TNF therapy, complete response was observed in $21 \%-25 \%$ of patients in interventional studies and in 92\%-100\% patients in non-interventional studies. Similar results were observed for other cutaneous manifestations, such as erythema nodosum. Complete response after anti-TNF treatment was also observed in patients with joints involvement with a reduction in arthralgia prevalence from $47.1 \%$ to $26.8 \%$ and arthritis prevalence from $8.7 \%$ to $2.1 \%$.

\section{LIMITATIONS OF ANTI-TNF USE}

\section{Safety and adverse events}

Although the overall safety profile of anti-TNF is considered satisfactory, there are some concerns about the higher risk of adverse events with these agents, including infection, malignancy, metabolic and immunological disorders, specially when used in combination with thiopurines. Susceptibility to infection is of significant concern following the long-term treatment with anti-TNF. Analysis from the CD TREAT registry ${ }^{(42)}$ found that IFX treatment was associated with a significant increased risk of serious infections (unadjusted rates of 2.06 per 100 patient-years) compared with the other treatments-only group (1.42 per 100 patient-years). The risk of opportunistic infections is also clearly increased with anti-TNF treatment. Due to the role of TNF in the formation of granulomas, anti-TNF-a therapy has been associated with increased risk of tuberculosis reactivation ${ }^{(43)}$. It is important to emphasize that disease activity itself and treatment with steroids and narcotic analgesics were also linked with infectious complications. Despite the increased risk of serious infection with IFX, mortality rate was similar between IFX and other-treatmentsonly-treated CD patients ${ }^{(42)}$.

An important adverse event reported with anti-TNF treatment is the occurrence of skin lesions ${ }^{(44)}$. A retrospective cohort ${ }^{(45)}$ analyzed skin lesions of 917 patients associated with the use of anti-TNF therapy. It was shown that $29 \%$ of patients developed drug-induced skin lesions as follows: psoriasiform eczema (30.6\%), eczema $(23.5 \%)$, xerosis cútis $(10.6 \%)$, palmoplantar pustulosis $(5.3 \%)$, psoriasis $(3.8 \%)$ and others $(26.1 \%)$. All the lesions reported occurred between the 3rd and 4th infusion of IFX and discontinuation of therapy was rarely required.

A great concern with the use of anti-TNF is related to the increased risk for malignancy. A retrospective study comparing patients on ADA monotherapy with those on combination therapy with immunossupressants conduced by Osterman et al. ${ }^{(46)}$ demonstrated no increase in lymphoma risk with ADA monotherapy. On the other hand, the authors observed an eightfold increase in lymphoma risk in patients on combination therapy with immunosuppressant compared with the general population, suggesting that the increased risk is likely attributable to the immunomodulator. Similarly, the REFURBISH study ${ }^{(47)}$ found that the risk of T-cell non-Hodgkin's lymphoma in IBD patients is not increased with the use of anti-TNF monotherapy, however, when anti-TNF is used in combination with thiopurine therapy this risk is higher.

On the other hand, a recent French cohort study ${ }^{(48)}$ analyzed the risk of lymphoma in patients with IBD which were exposed to thiopurines and anti-TNF agents (alone or in combination). The use of thiopurine or anti-TNF monotherapy was associated with a small but statistically significant increased risk of lymphoma. However, the risk was higher with combination therapy.

\section{Loss of response and therapeutic drug monitoring (TDM)}

Although anti-TNF agents are effective in treating IBD, primary failures of anti-TNF induction therapy occur in up to $40 \%$ of patients in clinical trials and in 10\%-20\% in clinical series ${ }^{(7,49,50)}$. Moreover, almost half of patients with initial response develop secondary loss of response within the first year ${ }^{(51)}$. Part of this failure to anti-TNF is mediated by pharmacokinetic issues related to undetectable or subtherapeutic drug concentrations with or without antidrug antibodies ${ }^{(52)}$.

A recent prospective real-life study (PANTS) ${ }^{(53)}$ involving 1601 $\mathrm{CD}$ patients naive for biological therapy treated with IFX or ADA concluded that immunogenicity is significantly associated with non-remission at week 54 . Moreover, concomitant therapy with immunomodulators can reduce immunogenicity in IFX and also in ADA therapy, suggesting better outcomes when these drugs are used in association.

Measuring drug levels and determination of the presence of antidrug antibodies has been shown to be useful in guiding the treatment strategy once it has the potential of identifying those which will benefit from dose escalation and those which will be better managed by switching to an alternate drug within or outside the drug class. However, more data are needed to define the role of TDM into clinical practice specially regarding the definition the optimal thresholds to target ${ }^{(54,55)}$.

In this setting, therapeutic drug monitoring (TDM) has been implemented as an auxiliary tool for treatment decision-making. While reactive TDM has an established role for managing secondary loss of response and seems to be more cost-effective compared with empiric dose escalation, proactively monitoring of patients in stable remission remains controversial ${ }^{(56)}$.

A retrospective observational cohort study ${ }^{(57)}$ observed that reactive TDM to guide IFX dose adjustment compared with clinical decision making alone is associated with higher post adjustment clinical response, endoscopic remission and fewer hospitalizations.

However, recent data demonstrate that proactive TDM to potentially prevent future flare and loss-of-response in a treat-to-target 
therapeutic approach may arise as a novel strategy to optimize anti-TNF therapy efficacy, safety, and cost ${ }^{(58-60)}$.

Preliminary studies indicate that drug titration to a target trough level, performed in patients with clinical response, can also improve the efficacy of anti-TNFs ${ }^{(61-65)}$, preventing undetectable or low drug levels that consequently lead to immunogenicity and loss-of-response or infusion reactions ${ }^{(66)}$.

Recently, the American Gastroenterological Association $(A G A)^{(67)}$ suggested the use of reactive TDM in the context of secondary loss of response to anti-TNF therapy aiming trough concentrations of IFX $\geq 5 \mu \mathrm{g} / \mathrm{mL}$, ADA $\geq 7.5 \mu \mathrm{g} / \mathrm{mL}$, and CTZ $\geq 20 \mu \mathrm{g} / \mathrm{mL}$. However, the lack of data determining specific cutoffs and timepoints limit the overspread use of proactive TDM in clinical practice.

\section{CONCLUSION}

The use of drugs targeting anti-TNF has greatly advanced the therapeutic armamentarium for IBD and have become the cornerstone of treatment for moderate to severe UC and CD by improving quality of life and decreasing the risk of surgery and hospitalization, especially when used early in the treatment course.

Anti-TNFs agents have the best long-term evidence of efficacy in IBD with an acceptable safety profile with proven effectiveness for both induction and maintenance therapy, decreasing corticosteroid exposure and promoting mucosal healing.
The greatest concerns during the use of anti-TNF agents are mainly due to infectious events and immunogenicity. The concomitant use of immunomodulator can prevent the development of neutralizing anti-drug antibodies and increase trough levels of biologics, but, conversely, may increase the risk of infections and malignancies.

In the absence of head-to-head comparisons, the choice of the biological agent may be challenging and should take into account several variables. This comprehensive review highlights the specific scenarios in which the evidence supports the use of anti-TNFs as first-line agents, such as acute severe ulcerative colitis, fistulizing $\mathrm{CD}$, and extra-intestinal manifestations of IBD. Moreover, these agents may be considered an appropriate treatment in the setting of pregnancy and prevention of post-operative recurrence.

\section{Authors' contribution}

All authors equally contributed to this paper with conception and design of the study, literature review and analysis, drafting and critical revision and editing, and final approval of the final version.

\section{Orcid}

Camila Cunha Gonzaga Lima: 0000-0002-8433-2832.

Natália Sousa Freitas Queiroz: 0000-0003-2857-0825.

Carlos Walter Sobrado: 0000-0003-4486-9894.

Gustavo Luís Rodela Silva: 0000-0002-1314-7357.

Sérgio Carlos Nahas: 0000-0002-2268-4146.

Lima CCG, Queiroz NSF, Sobrado CW, Silva GLR, Nahas SC. Análise crítica do uso dos anti-TNF na era dos novos agentes biológicos na doença inflamatória intestinal. Arq Gastroenterol. 2020;57(3):323-32.

RESUMO - Contexto - As doenças inflamatórias intestinais (DII), tanto a doença de Crohn (DC) como a retocolite ulcerativa (RCU), são doenças crônicas imunomediadas que se apresentam com períodos de surto e remissão e requerem terapia a longo prazo. A terapia com anti-fator de necrose tumoral (anti-TNF) tem mudado o manejo da doença reduzindo a necessidade de hospitalizações, cirurgias e melhorando a qualidade de vida dos pacientes. Objetivo - O objetivo do presente trabalho é apresentar uma revisão sobre a importância dos agentes anti-TNF no contexto da DII, levando em consideração situações em que essas drogas são usadas como terapia de primeira linha. Métodos - Revisão narrativa baseada nas melhores evidências disponíveis na literatura através de buscas feitas nas bases de dados MedLine e PubMed até abril de 2020, utilizando as seguintes palavras chaves: "doença inflamatória intestinal", "agentes anti-TNF" e "terapia biológica". Conclusão - A terapia biológica permanece sendo fundamental no tratamento da DII. Na ausência de estudos "head-to-head" comparando os biológicos entre si, a escolha do agente biológico pode ser um desafio na prática clínica e múltiplas variáveis devem ser levadas em consideração. Os agentes anti-TNF devem ser considerados terapia de primeira linha em situações específicas como na colite ulcerativa aguda grave, na doença de Crohn fistulizante e nas manifestações extra-intestinais da doença inflamatória intestinal, uma vez que há evidências científicas robustas que sustentam a sua eficácia e segurança nessas situações.

DESCRITORES - Doenças inflamatórias intestinais. Fator de necrose tumoral alfa, antagonistas \& inibidores. Terapia biológica. Doença de Crohn, tratamento farmacológico. Colite ulcerativa, tratamento farmacológico.

\section{REFERENCES}

1. Rutgeerts P, Feagan BG, Lichtenstein GR, Mayer LF, Schreiber S, Colombel JF, et al. Comparison of scheduled and episodic treatment strategies of infliximab in Crohn's disease. Gastroenterology. 2004;126:402-13.

2. Lichtenstein GR, Yan S, Bala M, Blank M, Sands BE. Infliximab maintenance treatment reduces hospitalizations, surgeries, and procedures in fistulizing Crohn's disease. Gastroenterology. 2005;128:862-9.

3. Mitrev N, Leong RW. Therapeutic drug monitoring of anti-tumour necrosis factor- $\alpha$ agents in inflammatory bowel disease. Expert Opinion on Drug Safety. 2016;16:303-17.

4. Roda G, Jharap B, Neeraj N, Colombel J-F. Loss of Response to Anti-TNFs: Definition, Epidemiology, and Management. Clin Transl Gastroenterol. 2016;7(1):e135.
5. Targan SR, Hanauer SB, Deventer SJV, Mayer L, Present DH, Braakman T, et al. A Short-Term Study of Chimeric Monoclonal Antibody cA2 to Tumor Necrosis Factor $\alpha$ for Crohns Disease. N Engl J Med. 1997;337:1029-36.

6. Hanauer SB, Sandborn WJ, Rutgeerts P, Fedorak RN, Lukas M, Macintosh D, et al. Human Anti-Tumor Necrosis Factor Monoclonal Antibody (Adalimumab) in Crohn's Disease: the CLASSIC-I Trial. Gastroenterology. 2006;130:323-33.

7. Hanauer SB, Feagan BG, Lichtenstein GR, Mayer LF, Schreiber S, Colombel JF, et al. Maintenance infliximab for Crohns disease: the ACCENT I randomised trial. The Lancet. 2002;359:1541-9.

8. Schnitzler F, Fidder H, Ferrante M, Noman M, Arijs I, Assche GV, et al. Longterm outcome of treatment with infliximab in 614 patients with Crohns disease: results from a single-centre cohort. Gut. 2008;58:492-500. 
9. Singh S, Fumery M, Sandborn WJ, Murad MH. Systematic review and network meta-analysis: first- and second-line biologic therapies for moderate-severe Crohns disease. Aliment Pharmacol Ther. 2018;48:394-409.

10. Present DH, Rutgeerts P, Targan S, Hanauer SB, Mayer L, Hogezand RV, et al. Infliximab for the Treatment of Fistulas in Patients with Crohns Disease. N Engl J Med. 1999;340:1398-405

11. Sands BE, Anderson FH, Bernstein CN, Chey WY, Feagan BG, Fedorak RN, et al. Infliximab Maintenance Therapy for Fistulizing Crohns Disease. N Engl J Med. 2004;350:876-85.

12. Colombel JF, Sandborn WJ, Rutgeerts P, Enns R, Hanauer SB, Panaccione R, et al. Adalimumab for Maintenance of Clinical Response and Remission in Patients With Crohn's Disease: The CHARM Trial. Gastroenterology. 2007;132:52-65.

13. Swoger JM, Regueiro M. Preventive therapy in postoperative Crohn's disease Current Opinion in Gastroenterology. 2010;26:337-43.

14. Bernell O, Lapidus A, Hellers G. Risk Factors for surgery and postoperative recurrence in Crohn's disease. Ann Surg. 2000;231:38.

15. Buisson A, Chevaux J-B, Allen PB, Bommelaer G, Peyrin-Biroulet L. Review article: the natural history of postoperative Crohns disease recurrence. Aliment Pharmacol Ther. 2012;35:625-33.

16. Regueiro M, Schraut W, Baidoo L, Kip KE, Sepulveda AR, Pesci M, et al. Infliximab Prevents Crohns Disease Recurrence After Ileal Resection. Gastroenterology. 2009;136(2).

17. Regueiro M, Feagan BG, Zou B., Johanns J, Blank MA, Chevrier M, et al. Infliximab reduces endoscopic, but not clinical, recurrence of Crohn's disease after ileocolonic resection. Gastroenterology. 2016;150(7).

18. Cruz PD, Kamm MA, Hamilton AL, Ritchie KJ, Krejany EO, Gorelik A, et al Crohns disease management after intestinal resection: a randomised trial. The Lancet. 2015;385:1406-17.

19. Savarino E, Bodini G, Dulbecco P, Assandri L, Bruzzone L, Mazza F, et al. Adalimumab Is More Effective Than Azathioprine and Mesalamine at Preventing Postoperative Recurrence of Crohn's Disease: A Randomized Controlled Trial. Am J Gastroenterol. 2013;108:1731-42.

20. Rutgeerts P, Sandborn WJ, Feagan BG, Reinisch W, Olson A, Johanns J, et al. Infliximab for Induction and Maintenance Therapy for Ulcerative Colitis. N Engl J Med. 2005;353:2462-76.

21. Reinisch W, Sandborn WJ, Hommes DW, Dhaens G, Hanauer S, Schreiber S, et al. Adalimumab for induction of clinical remission in moderately to severely active ulcerative colitis: results of a randomised controlled trial. Gut. 2011; 60:780-7.

22. Colombel JF, Panés J, D’Haens G, Schreiber S, Panaccione R, Peyrin-Biroulet L, et al. OP01 Higher vs. standard adalimumab maintenance regimens in patients with moderately to severely active ulcerative colitis: Results from the SERENE-UC maintenance study. J Crohns Colitis. 2020; 14(Suppl 1):S001-S001.

23. Sandborn WJ, Assche GV, Reinisch W, Colombel JF, Dhaens G, Wolf DC, et al. Adalimumab Induces and Maintains Clinical Remission in Patients With Moderate-to-Severe Ulcerative Colitis. Gastroenterology. 2012;142(2).

24. Tursi A, Elisei W, Faggiani R, Allegretta L, Valle ND, Forti G, et al. Effectiveness and safety of adalimumab to treat outpatient ulcerative colitis. Medicine. 2018;97(34)

25. Sandborn WJ, Feagan BG, Marano C, Zhang H, Strauss R, Johanns J, et al Subcutaneous Golimumab Maintains Clinical Response in Patients With Moderate-to-Severe Ulcerative Colitis. Gastroenterology. 2014;146(1).

26. Singh S, Fumery M, Sandborn WJ, Murad MH. Systematic review with network meta-analysis: first- and second-line pharmacotherapy for moderate-severe ulcerative colitis. Aliment Pharmacol Ther. 2017;47:162-75.

27. Sands BE, Tremaine WJ, Sandborn WJ, Rutgeerts PJ, Hanauer SB, Mayer L, et al. Infliximab in the Treatment of Severe, Steroid-Refractory Ulcerative Colitis: A Pilot Study. Inflammatory Bowel Diseases. 2001;7:83-8.

28. Järnerot G, Hertervig E, Friis-Liby I, Blomquist L, Karlén P, Grännö C, et al. Infliximab as Rescue Therapy in Severe to Moderately Severe Ulcerative Colitis: A Randomized, Placebo-Controlled Study. Gastroenterology. 2005;128: 1805-11.

29. Gustavsson A, Järnerot G, Hertervig E, Friis-Liby I, Blomquist L, Karlén P, et al. Clinical trial: colectomy after rescue therapy in ulcerative colitis - 3-year follow-up of the Swedish-Danish controlled infliximab study. Aliment Pharmacol Ther. 2010;32:984-9.

30. Gibson DJ, Heetun ZS, Redmond CE, Nanda KS, Keegan D, Byrne K, et al. An accelerated infliximab induction regimen reduces the need for early colectomy in patients with acute severe ulcerative colitis. Clin Gastroenterol Hepatol. 2015;13(2).

31. Nalagatla N, Falloon K, Tran G, Borren NZ, Avalos D, Luther J, et al. Effect of Accelerated Infliximab Induction on Short- and Long-term Outcomes of Acute Severe Ulcerative Colitis: A Retrospective Multicenter Study and Meta-analysis. Clin Gastroenterol Hepatol. 2019;17(3).
32. Gisbert JP, Chaparro M. Safety of Anti-TNF Agents During Pregnancy and Breastfeeding in Women With Inflammatory Bowel Disease. Am J Gastroenterol. 2013; 108:1426-38.

33. Mahadevan, U., Martin, C. F., Sandler, R. S., Kane, S. V., Dubinsky, M., Lewis, J. D., et al. 865 PIANO: a 1000 patient prospective registry of pregnancy outcomes in women with IBD exposed to immunomodulators and biologic therapy. Gastroenterology. 2012;142:S-149.

34. Luu M, Benzenine E, Doret M, Michiels C, Barkun A, Degand T, et al Continuous Anti-TNF $\alpha$ Use Throughout Pregnancy: Possible Complications For the Mother But Not for the Fetus. A Retrospective Cohort on the French National Health Insurance Database (EVASION). Am J Gastroenterol. 2018;113:1669-77.

35. Van der Woude, C. J., Ardizzone, S., Bengtson, M. B., Fiorino, G., Fraser, G., Katsanos, K., et al. The second European evidenced-based consensus on reproduction and pregnancy in inflammatory bowel disease. J Crohns Colitis. 2015;9:107-24.

36. Danese S. Extraintestinal manifestations in inflammatory bowel disease. World Journal of Gastroenterology. 2005;11:7227.

37. Veloso FT, Carvalho J, Magro F. Immune-Related Systemic Manifestations of Inflammatory Bowel Disease. J Clin Gastroenterol. 1996;23:29-34.

38. Vavricka SR, Schoepfer A, Scharl M, Lakatos PL, Navarini A, Rogler G. Extraintestinal Manifestations of Inflammatory Bowel Disease. Inflamm Bowel Dis. 2015;21:1982-92.

39. Caspersen S, Elkjaer M, Riis L, Pedersen N, Mortensen C, Jess T, et al. Infliximab for Inflammatory Bowel Disease in Denmark 1999-2005: Clinical Outcome and Follow-Up Evaluation of Malignancy and Mortality. Clin Gastroenterol Hepatol. 2008;6:1212-7.

40. Barreiro-De-Acosta M, Lorenzo A, Domínguez-Muñoz JE. Efficacy of adalimumab for the treatment of extraintestinal manifestations of Crohns disease. Revista Española de Enfermedades Digestivas. 2012;104:468-72.

41. Peyrin-Biroulet L, Assche GV, Gómez-Ulloa D, García-Álvarez L, Lara N, Black CM, et al. Systematic Review of Tumor Necrosis Factor Antagonists in Extraintestinal Manifestations in Inflammatory Bowel Disease. Clin Gastroenterol Hepatol. 2017;15(1).

42. Lichtenstein GR, Feagan BG, Cohen RD, Salzberg BA, Diamond RH, Price S, et al. Serious Infection and Mortality in Patients With Crohn's Disease: More Than 5 Years of Follow-Up in the TREAT ${ }^{\mathrm{TM}}$ Registry. American Journal of Gastroenterology. 2012;107:1409-22

43. Xie X, Li F, Chen JW, Wang J. Risk of tuberculosis infection in anti-TNF- $\alpha$ biological therapy: From bench to bedside. J Microbiol Immunol Infect. 2014;47:268-74.

44. Ko JM, Gottlieb AB, Kerbleski JF. Induction and exacerbation of psoriasis with TNF-blockade therapy: A review and analysis of 127 cases. J Dermatolog Treat. 2009;20:100-8

45. Cleynen I, Moerkercke WV, Billiet T, Vandecandelaere P, Casteele NV, Breynaert C, et al. Characteristics of Skin Lesions Associated With Anti-Tumor Necrosis Factor Therapy in Patients With Inflammatory Bowel Disease. Ann Intern Med. 2015; $164: 10$

46. Osterman MT, Sandborn WJ, Colombel JF, Robinson AM, Lau W, Huang B, et al. Increased Risk of Malignancy With Adalimumab Combination Therapy, Compared With Monotherapy, for Crohns Disease. Gastroenterology. 2014;146(4).

47. Deepak P, Sifuentes H, Sherid M, Stobaugh D, Sadozai Y, Ehrenpreis ED. T-Cell Non-Hodgkin's Lymphomas Reported to the FDA AERS With Tumor Necrosis Factor-Alpha (TNF- $\alpha$ ) Inhibitors: Results of the REFURBISH Study. Am J Gastroenterol. 2013;108:99-105.

48. Lemaitre M, Kirchgesner J, Rudnichi A, Carrat F, Zureik M, Carbonnel F, et al. Association Between Use of Thiopurines or Tumor Necrosis Factor Antagonists Alone or in Combination and Risk of Lymphoma in Patients With Inflammatory Bowel Disease. Jama. 2017;318:1679.

49. Sprakes MB, Ford AC, Warren L, Greer D, Hamlin J. Efficacy, tolerability, and predictors of response to infliximab therapy for Crohns disease: A large single centre experience. J Crohns Colitis. 2012;6:143-53.

50. Ford AC, Sandborn WJ, Khan KJ, Hanauer SB, Talley NJ, Moayyedi P. Efficacy of Biological Therapies in Inflammatory Bowel Disease: Systematic Review and Meta-Analysis. Am J Gastroenterol. 2011;106:644-59.

51. Ben-Horin S, Kopylov U, Chowers Y. Optimizing anti-TNF treatments in inflammatory bowel disease. Autoimmun Rev. 2014;13:24-30.

52. Fine S, Papamichael K, Cheifetz AS. Etiology and Management of Lack or Loss of Response to Anti-Tumor Necrosis Factor Therapy in Patients With Inflammatory Bowel Disease. Gastroenterol Hepatol (NY). 2019;15:656-65.

53. Kennedy NA, Heap GA, Green HD, Hamilton B, Bewshea C, Walker GJ, et al. Predictors of anti-TNF treatment failure in anti-TNF-naive patients with active luminal Crohn's disease: a prospective, multicentre, cohort study. The Lancet Gastroenterology Hepatology. 2019;4:341-53.

54. Papamichael K, Cheifetz AS, Melmed GY, Irving PM, Casteele NV, Kozuch PL, et al. Appropriate Therapeutic Drug Monitoring of Biologic Agents for Patients With Inflammatory Bowel Diseases. Clin Gastroenterol Hepatol. 2019;17(9) 
55. Martins CDA, Moss AC, Sobrado CW, Queiroz NSF. Practical Aspects of Proactive TDM for Anti-TNF Agents in IBD: Defining Time Points and Thresholds to Target. Crohns \& Colitis 360. 2019;1(3). https://doi.org/10.1093/crocol/otz049

56. Ma C, Battat R, Jairath V, Casteele NV. Advances in Therapeutic Drug Monitoring for Small-Molecule and Biologic Therapies in Inflammatory Bowel Disease. Current Treatment Options in Gastroenterology. 2019;17:127-45.

57. Kelly OB, Donnell SO, Stempak JM, Steinhart AH, Silverberg MS. Therapeutic Drug Monitoring to Guide Infliximab Dose Adjustment is Associated with Better Endoscopic Outcomes than Clinical Decision Making Alone in Active Inflammatory Bowel Disease. Inflamm Bowel Dis. 2017;23:1202-9.

58. Pariente B, Laharie D. Review article: why, when and how to de-escalate therapy in inflammatory bowel diseases. Aliment Pharmacol Ther. 2014;40:338-53.

59. Steenholdt C, Brynskov J, Thomsen OØ, Munck LK, Fallingborg J, Christensen LA, et al. Individualised therapy is more cost-effective than dose intensification in patients with Crohn's disease who lose response to anti-TNF treatment: a randomised, controlled trial. Gut. 2013;63:919-27.

60. Steenholdt C, Brynskov J, Thomsen OØ, Munck LK, Fallingborg J, Christensen LA, et al. Individualized Therapy Is a Long-Term Cost-Effective Method Compared to Dose Intensification in Crohn's Disease Patients Failing Infliximab. Dig Dis Sci. 2015;60:2762-70.

61. Papamichael K, Cheifetz AS, Melmed GY, Irving PM, Casteele NV, Kozuch PL, et al. Appropriate Therapeutic Drug Monitoring of Biologic Agents for Patients With Inflammatory Bowel Diseases. Clin Gastroenterol Hepatol. 2019;17(9)
62. Papamichael K, Vajravelu RK, Vaughn BP, Osterman MT, Cheifetz AS. Proactive Infliximab Monitoring Following Reactive Testing is Associated With Bette Clinical Outcomes Than Reactive Testing Alone in Patients With Inflammatory Bowel Disease. J Crohns Colitis. 2018;12:804-10.

63. Casteele NV, Ferrante M, Assche GV, Ballet V, Compernolle G, Steen KV, et al Trough Concentrations of Infliximab Guide Dosing for Patients With Inflammatory Bowel Disease. Gastroenterology. 2015;148(7).

64. Papamichael K, Chachu KA, Vajravelu RK, Vaughn BP, Ni J, Osterman MT, et al. Improved Long-term Outcomes of Patients With Inflammatory Bowel Disease Receiving Proactive Compared With Reactive Monitoring of Serum Concentrations of Infliximab. Clinical Gastroenterology and Hepatology. 2017;15(10).

65. Vaughn BP, Martinez-Vazquez M, Patwardhan VR, Moss AC, Sandborn WJ Cheifetz AS. Proactive Therapeutic Concentration Monitoring of Infliximab May Improve Outcomes for Patients with Inflammatory Bowel Disease. Inflamm Bowel Dis. 2014;20:1996-2003.

66. Papamichael K, Osterman MT, Siegel CA, Melmed GY, Dubinsky MC, Colombel J-F, et al. Using Proactive Therapeutic Drug Monitoring of Anti-Tumor Necrosis Factor Therapy in Inflammatory Bowel Disease: From an Old Concept to a Future Standard of Care? Gastroenterology. 2018;154:1201-2.

67. Feuerstein JD, Nguyen GC, Kupfer SS, Falck-Ytter Y, Singh S, Gerson L, et al. American Gastroenterological Association Institute Guideline on Therapeutic Drug Monitoring in Inflammatory Bowel Disease. Gastroenterology. 2017;153:827-34. 